\title{
HOW WELL DOES BORDERING FOREST COMPOSITION PREDICT TREE ESTABLISHMENT IN UTILITY CORRIDORS?
}

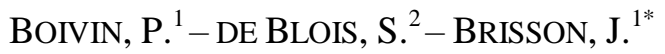 \\ ${ }^{I}$ Institut de recherche en biologie végétale, Département de sciences biologiques, Industrial \\ Research Chair in Phytotechnology, Université de Montréal, 4101 East, Sherbrooke St., \\ Montréal (Qc) H1X 2B2, Canada
}

${ }^{2}$ Department of Plant Science and McGill School of Environment, McGill University, Raymond Building, 21111 Lakeshore Road, Ste. Anne de Bellevue (Qc) H9X 3V9, Canada

*Corresponding author

e-mail: jacques.brisson@umontreal.ca; phone: +1-514-343-2116

(Received $26^{\text {th }}$ Feb 2018; accepted $21^{\text {st }}$ May 2018)

\begin{abstract}
The relation between bordering tree forest composition, seed rain and tree seedling establishment was estimated in a powerline corridor of southern Quebec (Canada). Red maple was the most important tree species in the bordering forests, accounting for nearly half of the 18 tree species found, in terms of basal area. Seeds from 10 tree species were found in the seed traps, the large majority of which being from gray birch, followed by red maple, paper birch, and white ash. A good proportion of seeds from gray birch and eastern hemlock were dispersed in winter. Seedlings from 14 tree species were sampled in the right-of-way, the large majority being from red maple and gray birch. The relation between nearby bordering tree, seed and seedling abundances varied among tree species. Seed abundance collected within a single year appeared to be poorly related to tree representation and seedling abundance, suggesting high interannual variation in seed production. Distance to seed source was weakly related to seedling establishment for some species such as gray birch. However, for many species, tree composition in the neighboring forest was a good predictor of nearby seedling establishment, implying that dispersal limitation may be an important factor in determining tree composition.
\end{abstract}

Keywords: seed dispersal, seedling establishment, tree composition, Acer rubrum, Betula populifolia

\section{Introduction}

Tree establishment in open sites may be viewed as beneficial or detrimental depending on management purposes. On sites assigned to forest production, natural establishment contributes to reforestation, and cutting practices frequently include protection of seeding trees or forest patches in order to insure sufficient seed sources (Solarik et al., 2010). Lack of natural tree establishment may necessitate direct seeding (St-Denis et al., 2013) or planting (Corbin and Holl, 2012). In powerline corridors, on the other hand, tree establishment is often a nuisance and costly cutting operations are needed to keep a low vegetation cover that does not interfere with operation and safety (de Blois et al., 2004), Understanding the factors that influence seedling establishment in open sites can therefore contribute to better planning and vegetation management for a variety of purposes.

Because they act as seed sources, trees bordering an opening should be the best predictor of recolonization pressure (Martínez-Orea et al., 2014). However, bordering forest composition and seedling composition in the opening may not always be closely related. First, annual seed production, germination rate, and interannual variation vary depending on species and tree size (Hill et al., 1995). Also, seed rain at a particular location further depends on proximity to seeding trees and seed dispersion. Finally, 
seedling establishment varies between species depending on biotic and abiotic factors such as seed size, seed predation, soil requirement, herbaceous cover, predation, or climatic condition (Gill and Marks, 1991). All these factors interact to determine recolonization or tree invasion pressure.

How accurately can we therefore predict tree establishment potential from bordering tree composition alone? This question is important especially in the context of integrated vegetation management (IVM), where the goal is to minimize environmental damages and costs. IVM practices require adapting management strategies to the local ecological context (Nowak and Ballard, 2005). If the goal is to prevent or reduce tree invasion as in many utility rights-of-way, a sound assessment of tree invasion pressure is crucial to design efficient interventions. A situation where there is high invasion potential from a fast growing but little competitive tree species, for example, may require active prevention with the sowing of a competitive herbaceous cover to control invasion (de Blois et al., 2004), while sites with low invasion pressure may be best treated by targeting specific invaders as needed.

The objective of this study is to assess the relation between bordering tree forest composition, seed rain, and seedling establishment in a powerline right-of-way of southern Quebec, Canada. The work presented here is part of an ongoing long-term project that aims to design and implement efficient integrated vegetation management practices in powerline rights-of-way corridors.

\section{Study site}

The study site is located in Roxton County ( $\left.45^{\circ} 54^{\prime} \mathrm{N}, 73^{\circ} 49^{\prime} \mathrm{W}\right)$, in the Montérégie Region of southern Quebec, Canada (Fig. 1).



Figure 1. Study site 
This region has a humid continental climate with hot summers and cold winters. The mean annual temperature and total precipitation are, respectively, $6.3{ }^{\circ} \mathrm{C}$ and $1215 \mathrm{~mm}$ for the years 1981 to 2010 (Granby meteorological station). Mean maximal temperature is $25.2^{\circ} \mathrm{C}$ in July and $-14.2^{\circ} \mathrm{C}$ in January (Environment Canada, 2015).

The sampling sites are distributed along a $14.6 \mathrm{~km}$ portion of a powerline right-ofway (Fig. 1). In this portion, the topography is slightly rugged, with a $79 \mathrm{~m}$ altitude difference between the first and last sampling site. A surficial deposit of sandy to gravel till lies over the bedrock made of calcareous shale and sandstone of the Sillery Formation (Prichonnet, 1984).

The Montérégie region is part of the Maple - Basswood Bioclimatic Domain (Ministère des Ressources naturelles du Québec, 2003) and the St. Lawrence Lowlands Ecoregion (Ecoregions Working Group, 1989). The studied powerline portion is mostly bordered by forests interspersed with cultivated fields and pastures. Mesic sites are mostly occupied by submature woodlands dominated by sugar maple (Acer saccharum) accompanied by red maple (Acer rubrum), yellow birch (Betula alleghaniensis), American beech (Fagus grandifolia), Ironwood (Ostrya virginiana) and eastern hemlock (Tsuga canadensis). These woodlands are often managed for maple sugar production. In the moderately drained sites, most of which are partially to severely disturbed by partial cutting, trembling aspen (Populus tremuloides), large-toothed aspen (Populus grandidentata), pin cherry (Prunus pensylvanica), paper birch (Betula papyrifera), white ash (Fraxinus americana) or gray birch (Betula populifolia) accompany red maple. Poorly drained sites are colonized by gray birch, balsam fir (Abies balsamea), willows (Salix sp), black ash (Fraxinus nigra) and white elm (Ulmus americana). Other common tree species found in the area include black cherry (Prunus serotina), eastern white cedar (Thuya occidentalis), tamarack (Larix laricina), balsam poplar (Populus balsamifera), red elm (Ulmus rubra) and eastern cottonwood (Populus deltoides) (Boivin et al., 2004).

The right-of-way is an $80 \mathrm{~m}$-wide corridor that has been deforested during a period going from September 1998 to February 1999, followed by the construction of the powerline. A portion of the right-of-way was grubbed and sown with an herbaceous mix while the rest was simply left as is.

\section{Methods}

Six sampling locations were selected in the right-of-way based on the following criteria: there had to be a forest border on each side of the right-of-way; the types of forest bordering the sampling sites had to cover a wide range of composition (Table 1). Data were collected in three phases over a period of 16 months (from April 2003 to August 2004) in order to characterize 1) forest border composition, 2) seed rain in the right-of-way, and 3) seedling establishment.

Bordering forest composition was sampled on July 2004 in two $80 \mathrm{~m}$ x 20m plots adjacent to the right-of-way, one on each side, with the long axis perpendicular to the right-of-way (Fig. 2). We identified and measured the diameter at breast height (DBH) of every tree $(\mathrm{DBH}>10 \mathrm{~cm})$ in each plot. For gray birch, for which significant seed production starts when the trees are still small, we also counted the number of individuals in each of two small size-classes (sapling 1: 1-5 cm DBH; and sapling 2: 5$10 \mathrm{~cm} \mathrm{DBH})$. Because tree size for a particular species is generally correlated to seed production, we measured tree importance in terms of basal area. 
Table 1. Characteristics of the sampled sites S1 to S6

\begin{tabular}{c|l|l|c}
\hline \multirow{2}{*}{ Name } & \multicolumn{2}{|c|}{ Bordering vegetation: dominant ${ }^{2}$ / co-dominant (forest age) } & $\begin{array}{c}\text { Distance } \\
\text { from S1 } \\
\text { (km) }\end{array}$ \\
\cline { 2 - 4 } & North border & South border & \\
\hline S1 & Rma / Sma (young) & Rma / Las (young) & 0 \\
\hline S2 & Rma / Sma (young) & Rma / Tas (young) & 0.4 \\
\hline S3 & Sma / Rma (mature) & Rma / Sma (sub-mature) & 3.8 \\
\hline S4 & Rma / Gbi (sub-mature) & Rma / Tas (sub-mature) & 8.6 \\
\hline S5 & Rma / Ael (young) & Bfi / Tas (sub-mature) & 13.7 \\
\hline S6 & Gbi / Rma (young) & Rma / Wil (young) & 14.0 \\
\hline
\end{tabular}

1: Sowing was done with an herbaceous seeding mix (Phleum pratense; Trifolium reprens; Trifolium pratense) for revegetation purposes

2: Ael $=$ American elm; Bfi = Balsam fir; Gbi $=$ Gray birch; Las = Large-toothed aspen; Rma = Red maple; Sma $=$ Sugar maple; Tas $=$ Trembling aspen; Wil = willows

3: young (20-40 years); sub-mature (41-60 years) and mature (61-80 years). Estimations based on photointerpretation and field validation, reported on ecoforest maps of the Ministère des forêts (Québec, 1994).

Because certain types of seeds - notably birch seeds - are known to disperse on snow in winter, we used two types of seed traps to fully evaluate tree seed rain in the right-of-way. For summer seed rain, we used seed traps made of funnels of $30 \mathrm{~cm}$ of diameter (opening surface: $0.09 \mathrm{~m}^{2}$ ), with a nylon mesh fastened at the small end to receive and store the seeds. The traps were fixed on a metal pole so that the opening end of the funnel was at $1 \mathrm{~m}$ above ground level in order to avoid the effect of the dense surrounding herbaceous vegetation. In April 2004, before seed fall of the earliest seed producer (red maple, starting seed fall in mid-May), 23 traps were installed in each sampling site, within a 10m-wide transect crossing the right-of-way (Fig. 2). Every month until late November, the nylon mesh were collected and replaced with new ones.

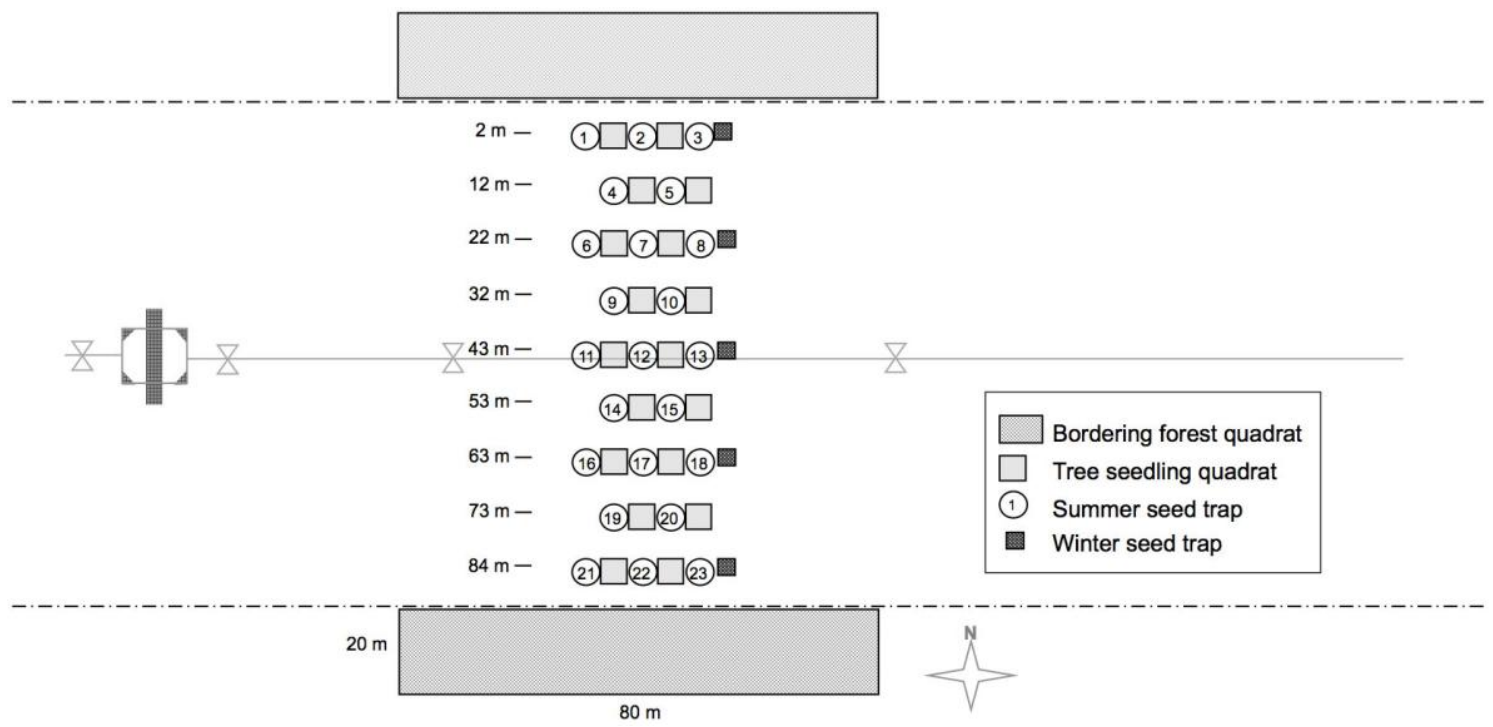

Figure 2. Sampling design in a sampling site of the powerline right-of-way 
Winter seed dispersion was evaluated using $1 \mathrm{~m}^{2}$ nylon cloth pinned to the ground and covered with a screen of the same size to assure an adhesive surface for seed collection. Five of these winter seed traps were uniformly located along a transect crossing the right-of-way in each of the six sampling sites in fall 2013, before the first snowfall (Fig. 2). The traps were collected in the following spring, during snowmelt, in March 2004, in order to collect all seeds deposited over the $1 \mathrm{~m}^{2}$ surface during winter. The snow remaining on the traps was melted and the organic material was filtered and added to those accumulated on the traps, and all tree seeds were sorted, dried, identified and counted. Birch seeds were identified using Kenneth and Brinkman (1974).

Tree seedlings were identified and counted in $181 \mathrm{~m}^{2}$ plots uniformly located in a transect crossing the right-of-way in each sampling sites of the same year. Information about the height and age were noted (Fig. 2). The number of seeds and seedlings counted in the plots along a transect were pooled in order to examine the relation between bordering tree, seed and seedling abundances between sites. For red maple and gray birch, the large number of seeds and seedlings allowed the study of their distribution along each transect, thus further allowing to study their spatial relation within sites.

Correlations using non-parametric Spearman tests were determined between 1) the distance to the nearest border and the abundances of seeds or seedlings (for red maple and gray birch only) and 2) seed abundance in summer and winter (for gray birch). Statistical tests were done using JMP statistical software version 6.

\section{Results and discussion}

All 6 sampling locations combined, 18 tree species were present in the forest plots bordering the rights-of-way (Table 2). Red maple was by far the most important tree species, accounting for nearly half of the total basal area for all trees, followed by sugar maple, trembling aspen, balsam fir, large-toothed poplar and gray birch. All the other tree species had a relative basal area lower than 3\%. We found seeds from 10 tree species in the winter and summer seed traps, the large majority of which being from gray birch $(80.7 \%)$, followed by red maple, paper birch, white ash, and yellow birch (Table 2). Note that there were no paper birch trees in the bordering forest plots despite the fact that it represented more than 5\% of the seeds in the seed traps, suggesting longdistance dispersal. A good proportion of seeds from gray birch, eastern hemlock, and yellow birch were dispersed in winter (Table 2). This was particularly notable for yellow birch, which had almost half of its seeds dispersed in winter, confirming the necessity of sampling winter-dispersed seeds for a complete assessment of seed rain at a particular location (Matlack, 1989).

We found no seeds for several tree species that are otherwise represented in the adjacent bordering forest plots, including species known to produce large number of wind-dispersed seeds such as trembling aspen and large-toothed poplar. This absence may be due to a large interannual difference in seed production, with low production the year of our sampling.

Seedlings from 14 tree species were sampled in the right-of-way, the large majority being from red maple and gray birch (Table 2). There is generally little correspondence for species relative abundance between the tree - seed - seedling datasets, but there is a close relation for the relative rank of a species between the tree and seedling datasets: of the 6 most abundant trees in the bordering forests, 5 are also the most represented in the 
seedling sets, with both red maple and trembling aspen keeping the same rank (Table 2). There is little relation, both in terms of relative abundance or rank, between seed abundance and either tree abundance in the bordering forest or seedling abundance in the right-of-way. Again, this may be due to large interannual difference in seed production (Houle 1999).

Table 2. Abundance and ranking of bordering trees, seeds and seedlings of the tree species in the right-of-way

\begin{tabular}{l|c|c|c|c|c|c|c|c|c}
\hline Species & \multicolumn{3}{|c|}{ Tree basal area } & \multicolumn{3}{c|}{$\begin{array}{c}\text { Seed density } \\
\text { (\% winter) }\end{array}$} & \multicolumn{3}{c}{ Seedlings density } \\
\hline & $\left(\mathrm{m}^{2} / \mathrm{ha}\right)$ & $\%$ & rank & Seeds/m & $\%$ & rank & Seedl./m & $\%$ & rank \\
\hline Red maple & 6.86 & 46.8 & 1 & 33.6 & 10.7 & 2 & 3.44 & 51.0 & 1 \\
\hline Sugar maple & 2.10 & 14.3 & 2 & 0.4 & 0.1 & 8 & 0.16 & 2.4 & 5 \\
\hline Trembling aspen & 1.28 & 8.7 & 3 & - & - & - & 0.25 & 3.7 & 3 \\
\hline Balsam fir & 1.19 & 8.1 & 4 & 1.3 & 0.4 & 6 & 0.17 & 2.5 & 4 \\
\hline Large-toothed aspen & 1.18 & 8.0 & 5 & - & - & - & 0.02 & 0.3 & 10 \\
\hline Gray birch & 0.70 & 4.8 & 6 & $254(17)$ & 80.7 & 1 & 2.42 & 35.9 & 2 \\
\hline American elm & 0.32 & 2.2 & 7 & - & - & - & - & - & - \\
\hline Black cherry & 0.31 & 2.1 & 8 & - & - & - & 0.03 & 0.4 & 9 \\
\hline Yellow birch & 0.15 & 1.0 & 9 & $3.6(47)$ & 1.1 & 5 & 0.06 & 0.9 & 7 \\
\hline White ash & 0.15 & 1.0 & 10 & 4.0 & 1.3 & 4 & 0.05 & 0.7 & 8 \\
\hline Eastern white cedar & 0.11 & 0.8 & 11 & 0.2 & 0.1 & 10 & $<0.01$ & 0.1 & 13 \\
\hline Tamarack & 0.08 & 0.5 & 12 & - & - & - & 0.02 & 0.3 & 10 \\
\hline American beech & 0.03 & 0.2 & 13 & - & - & - & - & - & - \\
\hline Ironwood & 0.03 & 0.2 & 14 & - & - & - & - & - & - \\
\hline Eastern hemlock & 0.03 & 0.2 & 15 & $0.4(21)$ & 0.1 & 9 & - & - & - \\
\hline Balsam poplar & 0.02 & 0.1 & 16 & - & - & - & - & - & - \\
\hline Red elm & 0.1 & 0.7 & 17 & - & - & - & - & - & - \\
\hline Pin cherry & 0.02 & 0.1 & 18 & 0.4 & 0.1 & 7 & 0.08 & 1.2 & 6 \\
\hline Paper birch & - & - & - & $16.9(0.2)$ & 5.4 & 3 & - & - & - \\
\hline Black ash & - & - & - & - & - & - & $<0.01$ & 0.1 & 13 \\
\hline Eastern cottonwood & - & - & - & - & - & - & 0.02 & 0.3 & 10 \\
\hline & & & & & & & \\
\hline
\end{tabular}

If we exclude species with little representation in the 3 data sets, we find that the relation between tree, seed, and seedling abundance in a particular sampling site varies largely among species (Fig. 3). The combined tree abundance of both borders is a good indicator of seedling presence within the right-of-way for red maple, sugar maple, balsam fir, white ash, and northern white cedar. Gardescu and Marks (2004) also found a close relationship between seedling emergence and seed source in red maple and white ash. The primary reason for this spatial relation is more likely attributed to a short distance dispersal than to local suitable habitat conditions since the absence of trees in a particular sampling site often results in a low number or in the absence of seeds (see sugar maple, balsam fir, white ash and eastern white cedar). For red maple, with trees 
present in all borders, there was a close relation between tree, seed and seedling abundances. For these species, seed dispersal is thus an important factor in explaining seedling establishment. In general, these species are also those that have the largest seeds, representing another example of the relation between dispersal limitation and seed size (Battaglia et al., 2008).
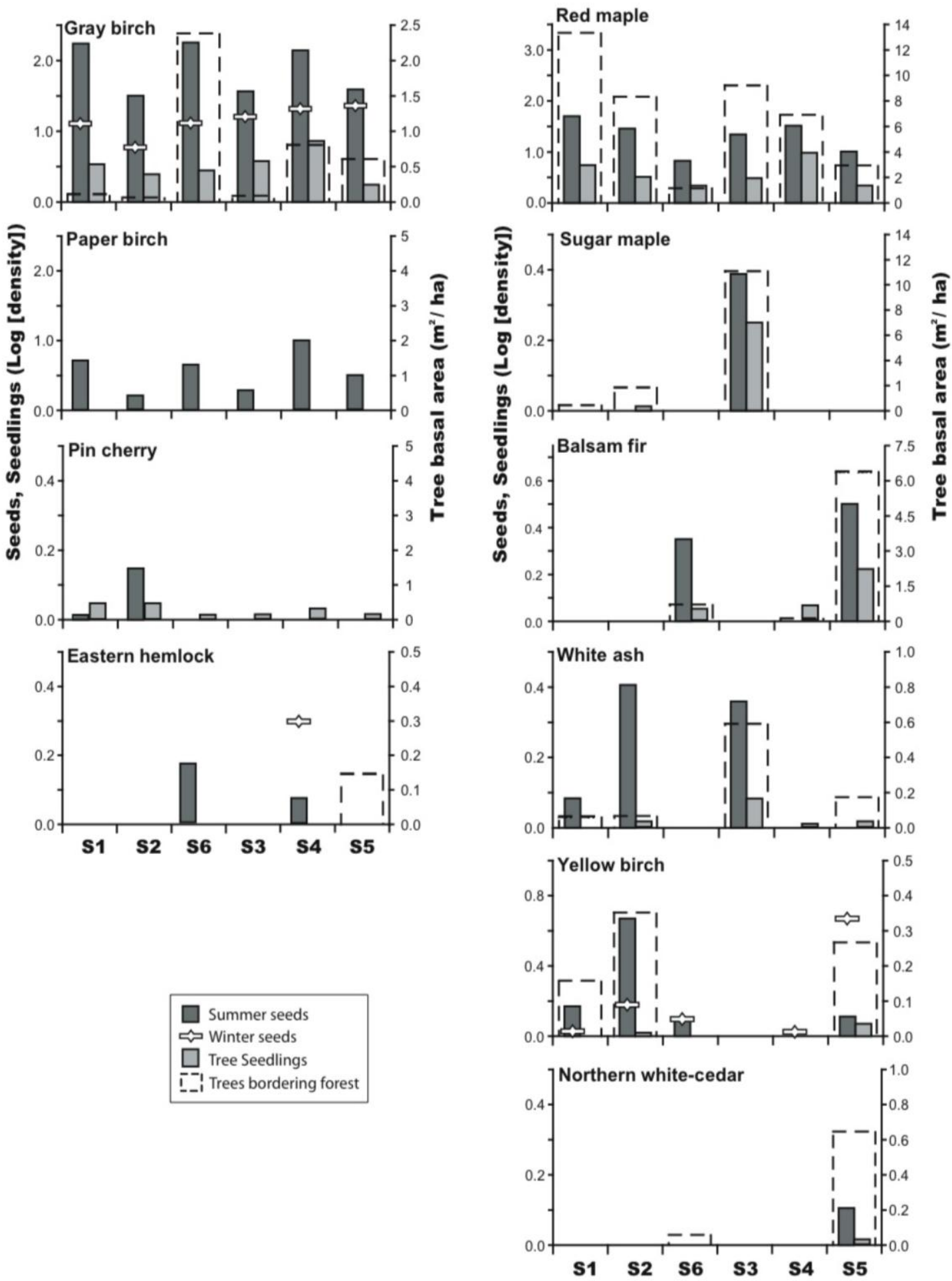

Figure 3. Abundance of trees (in the bordering forest), seeds, and seedlings in each sampling site of the powerline right-of-way for the most common tree species 
Other tree species showed little relation between tree and seed abundance within a sampling site. Gray birch seeds, both summer and winter dispersed, were present in great numbers in all sampling sites, irrespective of the abundance of seeding trees in the nearby border, suggesting a predominance of long-distance dispersal processes (Caughlin et al., 2014). Dispersal mechanisms in winter and summer did not create changes in dispersal patterns since the relative abundance in winter and summer appears to vary similarly. Paper birch seeds, present in all sites, also originated from more distant trees since they were absent in all borders. The large number of widely dispersed seeds combined with the total absence of seedlings suggest that paper birch does not find suitable conditions for seedling establishment in the right-of-way.

Dispersal of pin cherry seeds is known to be predominantly achieved by birds (Marks, 1974). While pin cherry trees are almost absent from the borders, seeds were found in all sites, although most often in small numbers. The two sites with the most pin cherry seeds were also the ones with the presence of seedlings. There was apparently no relation between the presence of eastern hemlock trees and the abundance of seeds (no seedlings were found), but the overall low tree and seed numbers in our sampling forces caution in interpreting this pattern.

Red maple and gray birch were sufficiently abundant in all sampling sites, both in terms of seeds and seedlings, to allow the study of their spatial patterns at the scale of a single sampling site. These two species are known to be aggressive colonizers (Lavoie, 1999, Abrams, 1998), and they both represent management problems in powerline rights-of-way (Boivin et al., 2004, Mercier et al., 2001). For red maple, there were often a decreasing number of seeds from the edge to the center of the right-of-way in several sampling sites (particularly apparent in S1, S2, S4, and S5) (Fig. 4). The same pattern occurred for seedlings in S5.

Overall, there was a significant negative correlation between the abundance of seeds and seedlings at a particular location in the rights-of-way and the distance from the nearest border ( $r=-0.65$ and -0.42 respectively, $\mathrm{p}<0.001$ in both cases). Both of these patterns indicate that the lower establishment in the center of the right-of-way is at least partly due to low seed dispersal distance at the scale of the transect. A greater tree seedling establishment at the edge of another powerline right-of-way was also related to the proximity of seeding trees and low seed dispersal distance by Brisson et al. (1997).

For gray birch, there was no relation between seed and seedling abundances and the distance to the nearest border ( $\mathrm{r}=-0.16$ and -0.02 respectively). Although spatial patterns of seed distribution for gray birch results from long-distance seed dispersion, the pattern along transects crossing the right-of-way implies smaller-scale dispersion processes, as shown by the apparent spatial autocorrelation in seed distribution within most sampling locations (Fig. 4). This may be due to local wind patterns within the rights-of-way. 


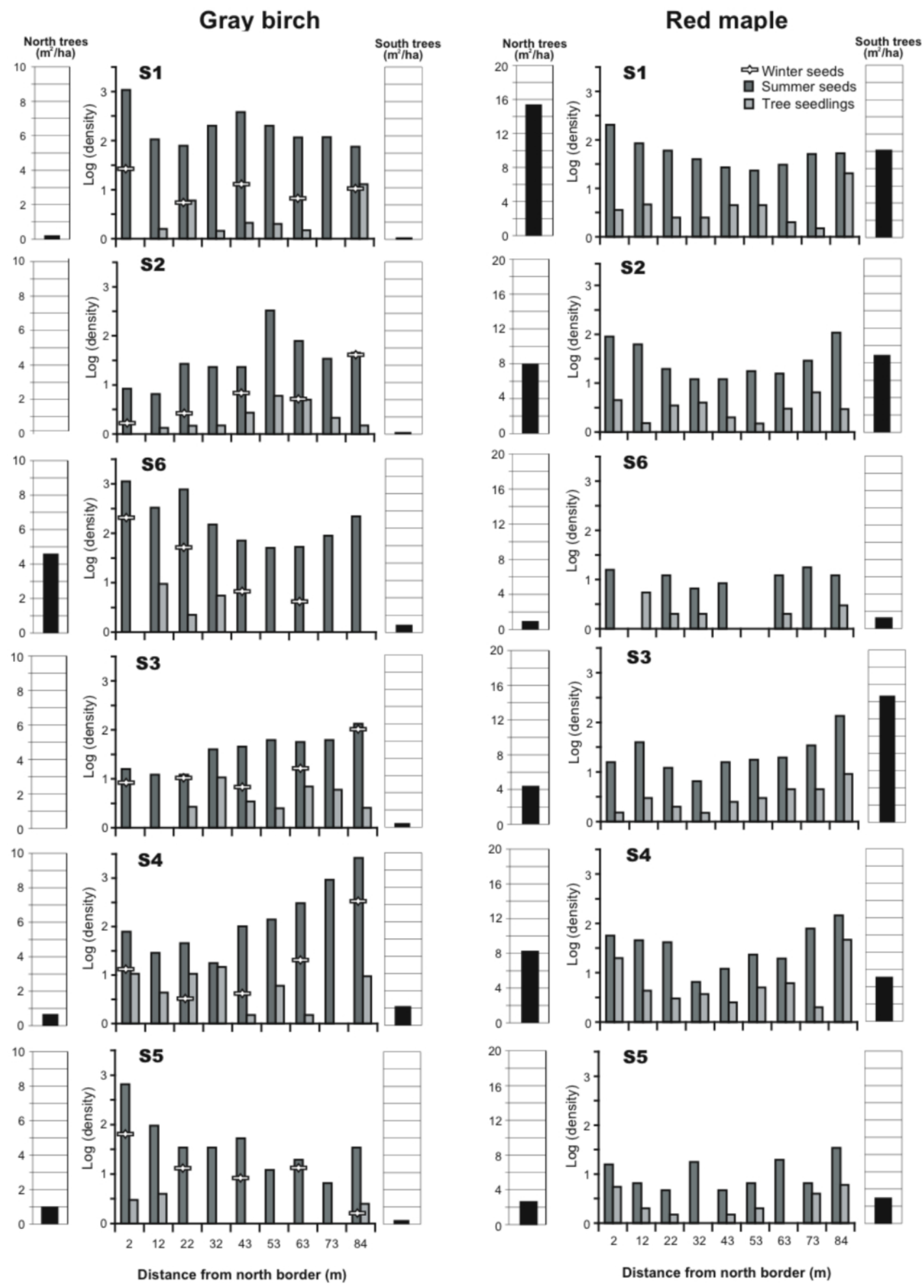

Figure 4. Tree abundance for each forest border and spatial distribution of seeds and seedlings across the right-of-way for gray birch and red maple. The x-axis represents the distance $(m)$, from the northern edge of the right-of-way to the center of the seed trap or seedling plot. At S3, the right-of-way was narrower, so that the transect had one plot less than for the other sites 


\section{Conclusion}

Seed abundance collected within a single year appeared to be poorly related to tree representation in the bordering forest and seedling abundance in the right-of-way, most likely due to interannual variation in seed production (Wesołowski et al. 2015). We found that the relation between nearby bordering tree, seed and seedling abundances varies among tree species. Distance to seed source was not so important for natural seedling establishment for some species such as gray birch. Winter seed dispersal may contribute to its long-distance dispersal. However, for many species, tree composition was an overall good predictor of nearby seedling establishment in terms of ranking. While this may be partially related to local suitable conditions, it also suggests that dispersal limitation may be an important factor in determining tree composition (Abiyu et al. 2016). These results may better inform powerline rights-of-way managers about corridor portions that may need greater plant control operations, but they are also relevant to other applications such as forest restoration and forestry.

Acknowledgements. We are grateful to Étienne Paradis, Bastien Fontaine, Mylène Francoeur, Carole Radix and Muriel Clericy for field assistance, and to Stéphane Daigle for statistical analysis. Financial support for this study was provided by Hydro-Québec.

Data accessibility. The field data used for this study are available at the Figshare online digital repository (https://figshare.com/); entry DOI: 10.6084/m9.figshare.6207431.

\section{REFERENCES}

[1] Abiyu, A., Teketay, D., Glatzel, G., Gratzereastern, G. (2016): Seed production, seed dispersal and seedling establishment of two afromontane tree species in and around a church forest: implications for forest restoration. - Forest Ecosystems 3:16.

[2] Abrams, M.D. (1998): The Red Maple Paradox. What explains the widespread expansion of red maple in eastern forest? - BioScience 48 : 355-364.

[3] Battaglia, L.L., Pritchett, D.W., Minchin, P.R. (2008) : Evaluating dispersal limitation in passive bottomland forest restoration. - Restoration Ecology 16: 417-424.

[4] Boivin, P., Brisson, J., Bouchard, A. (2004) : Maîtrise intégrée de la végétation dans la ligne Hertel - Des Cantons. Volet I : Suivi écologique; volet II : Ensemencement de mélanges herbacés stables; volet III : Maîtrise des rejets de souches et des drageons. Report prepared for Hydro-Québec TransÉnergie. Institut de recherche en biologie végétale, Montréal. 85 pages.

[5] Brisson, J., Meilleur, A., Fortin, M.-J., Bouchard, A. (1997): Edge effect on vegetation in rights-of-way. - In: Williams, J. R., Goodrich-Mahoney, J.W., Wisniewski, J.R., Wisniewski, J. (eds) 6th International symposium on environmental concerns in rights-ofway management. New Orleans, Louisiana. Elsevier Science, New York. pp. 25-34.

[6] Caughlin, T.T., Ferguson, J.M., Lichstein, J.W., Bunyavejchewin, S., Levey, D.J. (2014): The importance of long-distance seed dispersal for the demography and distribution of a canopy tree species. - Ecology 95: 952-962.

[7] Corbin, J.D., Holl, K.D. (2012): Applied nucleation as a forest restoration strategy. Forest Ecology and Management 265: 37-46.

[8] De Blois, S., Brisson, J., Bouchard, A. (2004): Herbaceous covers to control tree invasion: a synthesis of ecological concepts and applications. - Environmental Management 33(5): 606-619. 
[9] Ecoregions Working Group (1989): Ecoclimatic regions of Canada : first approximation. Committee on Ecological Land Classification, Canada (final compilation of the report, W. Strong and S.C. Zoltai). Sustainable Development Branch, Canadian Wildlife Service. 118 p. + map.

[10] Environment Canada (2015): Canadian climate normals 1981-2010. Internet: http://climate.weather.gc.ca/climate_normals/index_e.html (accessed July 2nd 2015).

[11] Gardescu, S., Marks, P. L. (2004): Colonization of old fields by trees vs. shrubs: seed dispersal and seedling establishment. - Journal of the Torrey Botanical Society: 53-68.

[12] Gill, D.S., Marks, P.L. (1991): Tree and shrub seedling colonization of old field in central New York. - Ecological Monographs 61: 183-205.

[13] Hill, J.D., Canham, C.D., Wood, D.M. (1995): Patterns and causes of resistance to tree invasion in rights-of-way. - Ecological Applications 5(2) : 459-470.

[14] Houle, G. (1999): Mast seeding in Abies balsamea, Acer saccharum and Betula alleghaniensis in an old growth, cold temperate forest of north-eastern North America. Journal of Ecology 87: 413-422.

[15] Kenneth, A., Brinkman, A. (1974): Betula L. Birch. U.S. Seeds of woody plants in the United States. Departement of Agriculture, Forest Service. - Agricultural Handbook 450. $883 \mathrm{pp}$.

[16] Lavoie, C. (1999): The spread of gray birch (Betula populifolia) in eastern Quebec: landscape and historical consideratrions. - Canadian journal of Botany 77 : 859-868.

[17] Marks, P.L. (1974): The role of pine cherry (Prunus pensylvanica L.) in the maintenance of stability in northern herdwood ecosystems. - Ecological Monographs 44 : 73-88.

[18] Martínez-Orea, Y., Orozco-Segovia, A., Castillo-Arguero, S., Collazo-Ortega, M., Zavala-Hurtado, J. A. (2014): Seed rain as a source of propagules for natural regeneration in a temperate forest in Mexico City. - Journal of the Torrey Botanical Society 142: 135150.

[19] Matlack, G.R. (1989): Secondary dispersal of seed across snow in Betula lenta, a gapcolonizing tree species. - Journal of Ecology 77: 853-869.

[20] Mercier, C., Brisson, J., Bouchard, A. (2001): Demographic Analysis of Tree Colonization in a 20-Year-Old Right-of-Way. - Environnemental Management 28 : 777787.

[21] Ministère des Ressources naturelles du Québec (2003) : Zones de végétation et domaines bioclimatiques $\mathrm{du}$ Québec. [Online] http://www.mrn.gouv.qc.ca/publications/forets/connaissances/zone-f.pdf.

[22] Nowak, C.A., Ballard, B.D. (2005): A framework for applying integrated vegetation management on rights-of-way. - Journal of Arboriculture 31: 28-37.

[23] Prichonnet, G. (1984): Géologie des formations de surfaces, Granby, Québec. Commission géologique du Canada. Ottawa. Carte 4-1984.

[24] Solarik, K.A., Lieffers, V.J., Volney, W.J.A., Pelletier, R., Spence, J.R. (2010): Seed tree density, variable retention, and stand composition influence recruitment of white spruce in boreal mixedwood forests. - Can. J. For. Res. 40: 1821-1832.

[25] St-Denis, A., Messier, C., Kneeshaw, D. (2013): Seed size, the only factor positively affecting direct seeding success in an abandoned field in Quebec, Canada. - Forests 4: $500-51$.

[26] Wesołowski, T., Rowiński, P, Maziarz, M. (2015): Interannual variation in tree seed production in a primeval temperate forest: does masting prevail? - European Journal of Forest Research 134: 99-112. 